\title{
Prospective Vision of the Implementation of E-learning Modules at the National Major University of San Marcos, Lima-Peru.
}

\author{
Roxanna Saldarriaga ${ }^{a}$, Hugo Vegab ${ }^{\mathrm{b}}$, Ciro Rodríguez ${ }^{\mathrm{c}}$, Cesar Salas ${ }^{\mathrm{d}}$, Yudi Guzmán ${ }^{\mathrm{e}}$ \\ a,b,c,d,e National Major University of San Marcos, Lima, Perú \\ a roxanna.saldarriaga@ unmsm.edu.pe, ORCID:0000-0002-1823-2470, b hvegah@unmsm.edu.pe, ORCID:0000-0002-4268- \\ 5808, ${ }^{c}$ crodriguezro@unmsm.edu.pe, ORCID:0000-0003-2112-1349, ${ }^{\mathrm{d}}$ cesar.salas@ unmsm.edu.pe, ORCID:0000-0002-2616- \\ 6207, eyudi.guzman@unmsm.edu.pe, ORCID:0000-0001-5306-5295
}

Article History: Received: 10 November 2020; Revised 12 January 2021 Accepted: 27 January 2021; Published online: 5 April 2021

\begin{abstract}
The article analyzes the incorporation of applied learning modules for undergraduate students of the Universidad Nacional Mayor de San Marcos' Administration career to learn more efficiently and dynamically. The Methodology considers the evaluation and review of the criteria taken in a survey to carry out the E-learning Implementation modules. The objective is to determine the factors that influence virtual teaching by validating the students' ability to use a new teaching process to apply any educational topic through this platform. As a result, five factors that influence virtual teaching were determined, validating students' capacity and predisposition to acquire new knowledge through new learning methodologies using virtual media;using these E-learning modules is recommended in conjunction with the Flipped Classroom or B-Learning methodology. It was also determined that only $30 \%$ of the students who have taken several virtual courses within their curriculum feel comfortable with this methodology since it requires an entirely didactic and easy to handle system to teach the subject matter..
\end{abstract}

Keywords: E-learning, Flipped Classroom, Blended, Gamification, Cloud Computing, Motivation, Prospective vision

\section{Introduction}

This article shows us, through different investigations, why it should be important to provide undergraduate students of the Administration career of the Universidad Nacional Mayor de San Marcos with the necessary knowledge through an E-learning platform. The impact of E-learning preparation on satisfaction and motivation was also analyzed.

The lack of motivation for virtual learning is being reflected considerably. According to [1], "The lack of equipment, applications, failures in existing equipment, lack of skills, platform organization, the correct use of applications, lack of training, program versions, connectivity, interruptions in uploading and downloading files, file sizes, high demand on networks, among others; All the above framed in the types of the digital divide, affected the motivation of the student and generated states of helplessness that led to desertion, which is why we must fight it because it is essential to know it to interact with today's world that is changing day by day in its technological processes".

Today, due to COVID-19, we must face this problem since we are forced to carry our education virtually, thus, we seek to reach students through interactive tools that allow the cognitive and functional development of ICT in conjunction with the subject, so both the teacher and the student must be willing to face the change positively and vitally for a good academic performance.

A survey was conducted on Information Technology and E-learning methodology at the Universidad Nacional Mayor de San Marcos in the Administrative Sciences career, resulting in only $30 \%$ of the students being motivated concerning ICT.

During the COVID 19 crisis, all students have been forced to use ICT in their educational environment; due to this event, various ways of applying teaching by this means have been sought. Creativity is one of the most important factors in capturing the attention of the child or young student. Given that this juncture has been presented suddenly, the problem is that there is a lack of factors that influence the realization of adequate virtual teaching. After applying the survey to UNMSM Administration students, it was found that $30 \%$ of them are motivated to use E-learning modules.

The research objective is to determine the factors that influence E-learning teaching and establish the best educational methodology for its implementation as a learning strategy,not to be a determining problem for the future of virtual classes. 


\section{Background Conceptos}

\subsection{Learning more about E-learning}

"The technology can easily deliver more sensory data than the human nervous system can process.”. [2]

According to the author, cognitive systems are limited because various information is competing for this limited capacity. The learner must choose the one that best fits.

Also, he suggests supporting people to get more involved with e-learning, more so if one has the knowledge to do so.

If part of e-learning, the task is to design environments that create experiences that foster the desired change in learner behavior. Change is fostered according to individual experiences

Some benefits as mentioned by the author:

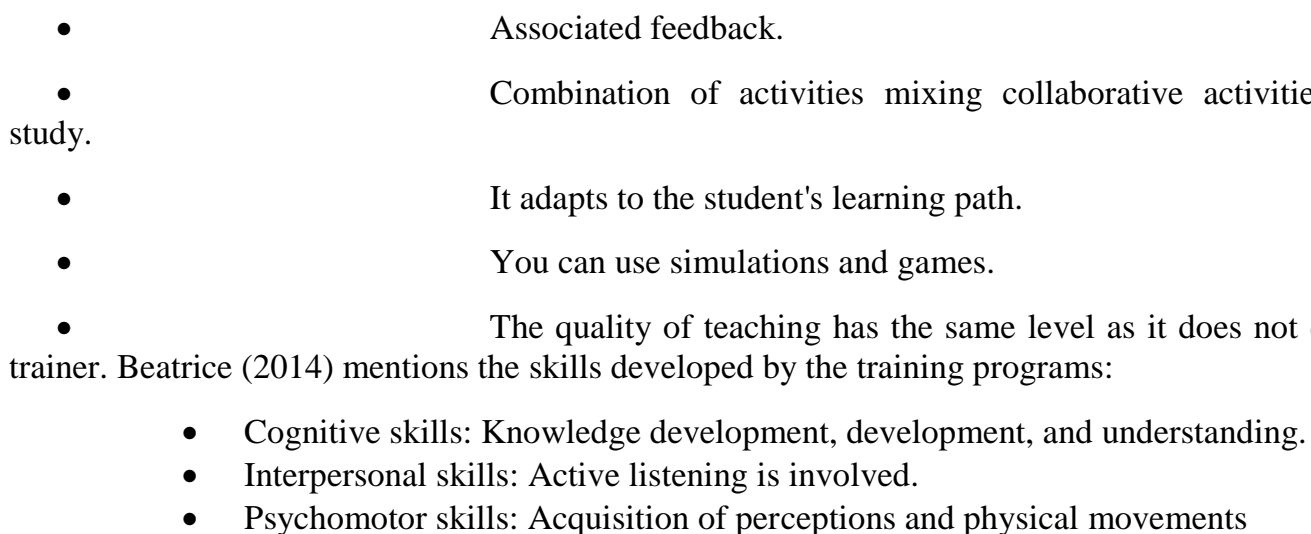

An example given is when multimedia designers use a circle and color to catch the eye, as shown in the following image:

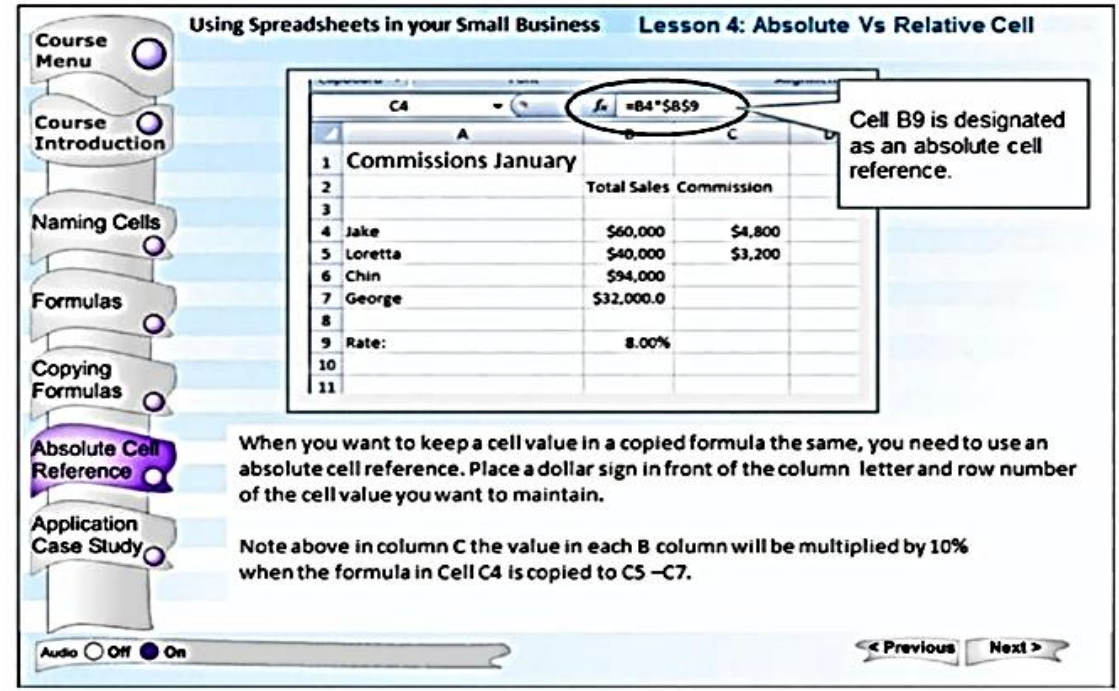

Figure 1. E-learning Design example. [2]

As [3]states that most of the courses are designed to develop cognitive skills. More interactive E-learning activities could be applied for thinking skills and the same practice through interactive games and feedback within the domain.

\subsection{Blended Learning}

The problem can be studied from 2 perspectives: The difficulties generated by the underlying model and the defects generated by a dominant economic factor in many projects. Underlying model: Reality. When looking at E-learning projects. [4]mentions that"it is a technology-enhanced distance learning program". 
E-learning has tried to apply a proven effective model for specific approaches, but it has some limits because not all the population is ready to do it.

Therefore, of the characteristics that have been shown, teacher tutoring is the most recent, and the following solutions are already being applied in important Spanish and Latin American institutions that apply E-learning:

Low-cost tutors

- $\quad$ Work overload

- $\quad$ Heavy reliance on learning materials that do not require human intervention.

- $\quad$ The request of recognized authors for elaborating materials that have then been allowed to cite them as "teachers".

- $\quad$ Pedagogical design, which had already been forgotten because it was preoccupied with marketing operations.

All this has led to the emergence of the Blended learning concept as an answer to face institutions since not all people approve of E-learning at $100 \%$.

"There are some concepts that require face-to-face lecture format. The optimal solution for this may be blended learning, a combination of online learning and classroom training. Blended learning includes face-to-face classroom practices that are combined with computer-mediated activities regarding content and delivery."[5].

"E-learning has become an increasingly popular alternative to face-to-face training, especially because of the possibility of combining personal and professional life with it.". [6]

\subsection{Flipped classroom orreverse methodology.}

In a Flipped classroom (FC) environment,the student can access learning content related to the new topics they will learn through lecture videos outside the classroom where they have face-to-face classes. Then, students work in the classroom to assimilate the new material they learned through cooperative learning activities, project work, and group discussions through videos[7][8]

This model aims to provide prior online access to content, learning materials and assist students in active and in-depth learning within the classroom.

However, to ensure the FC model's effectiveness, students must attend face-to-face classes with a certain level of knowledge.

On the other hand, the learner's E-learning readiness can ensure satisfaction and motivation in the FC model.

Students must complete specific online course requirements and come to class prepared.

According to the author, the Flipped Classroom, or Inverted Classroom (FC), "is a pedagogical approach in which activities that were normally done inside the classroom are done outside".

The main objective has been to evaluate a Flipped Classroom methodology on undergraduate students' academic performance in Social Work.

This methodology has demonstrated higher academic performance than traditional reading-based learning (BL)due to the development of different technological resources such as Google Drive, YouTube, Vimeo, Google Classroom, etc.

"It has been argued that future studies should have greater methodological rigor, a standardized FC format, and use assessment tools that evaluate the higher cognitive learning process rather than a test". [9]

\subsection{Information and Communication Technologies in Higher Education.}

In [10] shows various opinions regarding the concept of "technology" such as, for instance, [11] and[12]made the distinction between conventional technologies (based on speech, drawing, painting), new technologies (audiovisual resources), and advanced technologies (such as computer software design or animation). The author also mentions [13], who refers to 3 fields: telecommunications, computer science, image, and sound technologies. He also includes [14][15], who said that "information technologies are composed of any computer-based tool that people use to work with information, support information and process information needs".

Within this process, ICTs become more important and essential for the development of organizational flexibility in education. [16] mention that the ICT tools that companies have been incorporating to optimize processes, especially those related to documentary procedures, is the use of digital signatures. [17] affirm that proximity marketing with beacon devices is a growing strategy to reach customers adequately. [18] mention the 
main contributions toadopt technologies [19] mention that ICTs support business information integration to facilitate decision-making.

"They have also been involved in all fields of education, facilitating the transformation and optimization of most of the administrative processes, development of methodologies and access to a new group of higher education people.". [10][20][21]

According to[9], the benefits of ICT inclusion are:

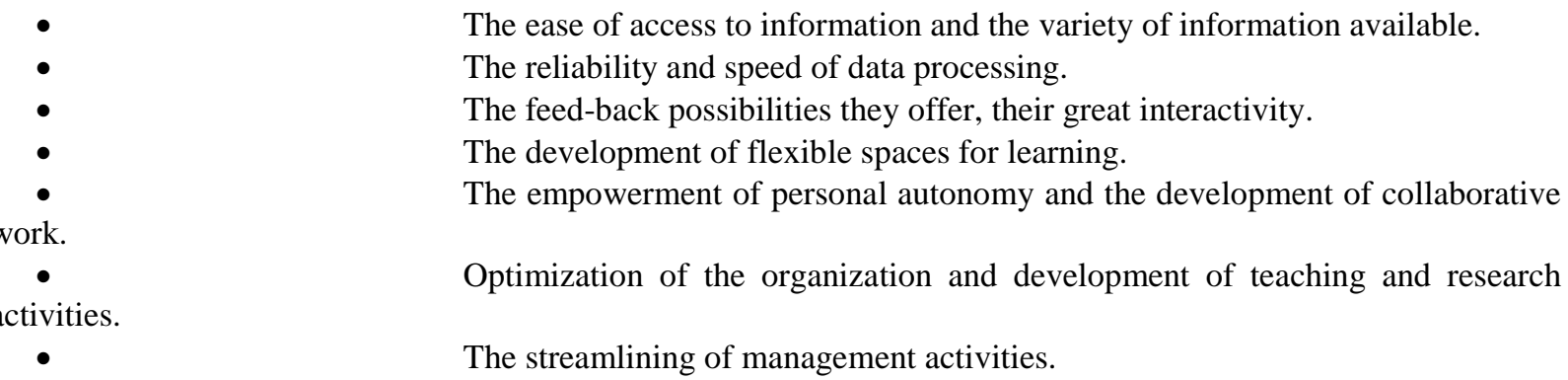

Measures that should be developed around the following aspects, according to the author:

$\bullet$

Training, technical, and pedagogical training of teachers.

Motivation and recognition.

$\bullet$

Investment

\subsection{Educational services using Cloud Computing technologies.}

The Cloud Computing paradigm is evolving and is mature enough to be used in the academic university environment.

Cloud Computing is a model for enabling convenient, on-demand network access to a shared pool of configurable computing resources (networks, servers, storage, applications, and services) that can be rapidly provisioned and withdrawn with minimal management effort interaction with the service provider.[22]

\section{Table1. Implementation Components.}

\begin{tabular}{l}
\hline Services Models \\
\hline Software as aService \\
\hline Platform as aService \\
\hline Infrastructureas aService \\
\hline Architectures \\
\hline Infrastructure \\
\hline Platform \\
\hline Application \\
\hline
\end{tabular}

\begin{tabular}{l}
\hline Deployment Models \\
\hline Private Cloud \\
\hline Cooperative Cloud \\
\hline Public Cloud \\
\hline Hybrid Cloud \\
\hline
\end{tabular}

\section{6. ¿How to improve quality, motivation, and student engagement in virtual education?}

"Online education is an optimal tool for the familiarization with technological environments and the development of skills autonomously and progressively. However, when blended and e-learning educational initiatives are carried out, they present a progressive demotivation of the students, ergo disinterest and lack of real commitment to the project".[23] 
Therefore, because of their educational benefits and their social usefulness and level of impact, hybrid or virtual training proposals must be of the highest quality.

The author introduces game-based learning techniques concerning the level of learner engagement with the aim of:

$\bullet$

$\bullet$
Identify modifiable elements within the online training process.

Determine the motivational factors to be reinforced.

Clarify proposals that promote e-learning.

As [23] mention that "It is important to include multimedia designs in virtual learning environments since they form a space for interaction between the teacher and the student, and at the same time, they allow the placement of digital and didactic materials in a previous design, which establishes learning activities that help students to achieve the proposed objectives. They also create spaces for discussion and work in research groups, and virtual communities and learning networks can be implemented around topics of common interest".

Another way to motivate the student is through Gamification; taking advantage of virtual tools, it is possible to include playful elements in the educational context under the E-learning modality.

"Although there is no single conceptualization of gamification in the educational sector, all of them present students with an experience that tends to be immersive, changing the principles of traditional education to new learning parameters, based on motivation and social identification, applying game mechanisms to make the pedagogical process more attractive and, ultimately, effective". [24]

\subsection{E-learning in the faceof the COVID 19 pandemic}

At the University of Botswanain India,[25]mentioned that they had to opt for the Moodle and Blackboard Learn (BBL) due to the pandemic tools, each with different advantages and disadvantages. Moodle may be less expensive than BBL, as BBL has interactive learning enhancements such as blogs, forums, and emails, whereas Moodle uses a business model and social constructivist approach, hence the low cost, which is why many higher institutions are making the transition to Moodle in all their faculties and departments.

It is becoming challenging to preserve education standards due to the limitations of finances, infrastructure, and other resources, including qualified and experienced human power. Learning provided through information technology (IT), to some extent, ensures high quality learning by providing the required information at a convenient place and at the right time. It is observed that E-learning emphasizes quality and effective presentation of information.[26].

Likewise,[27]surveyed students from various schools and universities in India, thus validating that E-learning provides rapid growth proving to be the best in all sectors, especially in Education during this blockade considering that the use of desktop, laptop or smartphones, and the internet, form an important component of this learning methodology.

The following is the authors' analysis:

Table2. Student's disposition towards E-learning. [26].

\begin{tabular}{lll}
\multicolumn{1}{c}{ Classificati } & \multicolumn{1}{c}{ Responde } & Percentage \\
on & nts & \\
\hline Yes & 144 & 82,29 \\
\hline No & 9 & 5,14 \\
\hline Perhaps & 22 & 12,57 \\
\hline Total & 175 & 100 \\
\hline
\end{tabular}

"More efforts are needed from the government and educational institutions to improve distance education. Investing in E-learning infrastructure, supporting students and teachers with necessary materials, workshops and training are important to increase their knowledge to adopt online learning. Facilitating the software and hardware of E-learning infrastructure is the main factor for the success of the educational process". [28] 
However, for[29],"virtual education is not applicable to develop the expected learning in the national university community, because high-end internet for provincial students is still one of the challenges that will have to be solved by the educational agents: governments, universities, students, professors, and civil society.".

\section{Methodology}

The present research seeks to know the incidence of the variables "Motivation for ICT" and "Utility of ICT to implement E-learning Modules", therefore, according to the type of research, the present one is "correlational", since it measures the degree of association between two variables, as it appears in the present research. The correlation will help us determine the feasibility of implementing E-learning modules to strengthen teaching.

\subsection{Unit of analysis}

It is made up of students of the Administration career at UNMSM, to whom a survey was applied to identify the importance of ICT for applying E-learning teaching methods.

\subsection{Population and Sample}

The population will be the students that make up the Administration career of the UNMSM. Students from the 3rd cycle to the 10th cycle have been considered for the sample since from that year onwards they take courses related to IT. To check the number of students, we have used the average number of vacancies in the admission exam (200) with a dropout rate per cycle of $-10 \%$.

Table3. RespondentPopulation

\begin{tabular}{ll}
\hline Cycle & Quantity \\
\hline IV & 145 \\
\hline V & 131 \\
\hline VI & 118 \\
\hline VII & 106 \\
\hline VIII & 95 \\
\hline IX & 86 \\
\hline X & 80 \\
\hline Total & $\mathbf{7 6 1}$
\end{tabular}

To calculate the size of the known sample, we use the following:

$\mathrm{n}=$ Sample size.

$\mathrm{N}=$ Population size 761

$\sigma=\quad$ Population Standard Deviation 0,5

$\mathrm{Z}=$ Levels of confidence 1,96

$\mathrm{e}=$ Acceptable Limit of Sampling Error 5\% $(0,05)$

$$
n=\frac{761 * 0.5^{2} * 1.96^{2}}{(761-1) * 0.05^{2}+0.5^{2} * 1.96^{2}}=\frac{730.9}{2.9}=256
$$

If I survey 256 people, $95 \%$ of the time, the data you want to measure will be within $\pm 5 \%$ of the data you observe in the survey.

\subsection{Data Collection}

The interview research methodology was used as the primary tool of the questionnaire.

To evaluate the research variables, we used an 11-question questionnaire. 


\subsection{Procedure}

For the survey-based data collection and distribution process, the following steps will be considered:

$\bullet$

Elaborate a list of questions asked about the factors to implement an E-learning module.

Elaborate invitations
end it digitally after approval of the dean of the faculty

- Wait for confirmation to proceed with the filling out of surveys.

\subsection{Data Reliability}

Cronbach's alpha will be used to validate the instrument. The instrument will be validated with professionals from Education and IT Management.

Cronbach's alpha is interpreted as follows: the closer the alpha value is to 1, the greater the consistency of the items analyzed. Therefore, if the alpha value is more significant than 0.7 , the instrument is accepted.

\subsection{Data Analysis and Interpretation}

The following have been considered for the statistical analysis:

$\bullet$



Reliability test using Cronbach's alpha.

Analysis of results

Discussion of results

\section{Results and Discussion}

The following analysis was made based on questions aboutusing ICTs and student motivation to determine the factors of implementing E-learning modules in conjunction with the best methodology to realize the student's knowledge.

It has been seen that the Flipped Classroom or inverted classroom is a good methodology for a good pace of learning since, under this modality, the student can investigate and solve their courses through these modules before the start of class, so that later, with the teacher in a synchronous way, they can validate the activities carried out.

Concerning B-learning or Blended, it is a semi face-to-face methodology; it would be used once returned to the face-to-face classes since this methodology can carry out activities using the E-learning modules synchronously or asynchronously.

\subsection{Reliability Analysis}

Reliability analysis was carried out using Cronbach's alpha based on 761 students surveyed to validate the instrument's reliability.

Likewise, the general criteria of [30][31][32] have been used, "since the questions have been measured using the Likert-type scale and, according to the authors, this type of items in this scale measure the same construct and are highly correlated".

Table 4: Cronbach's alpha Reliability Interpretation. [31]

\begin{tabular}{ll}
\hline Coefficientvalue & Interpretation \\
\hline$>0,9$ & Excellent \\
\hline Between $0,9-0,8$ & Good \\
\hline Between $0,8-0,7$ & Acceptable \\
\hline Between $0,7-0,6$ & Weak \\
\hline Between $0,6-0,5$ & Poor \\
\hline$<0,5$ & Not acceptable \\
\hline
\end{tabular}


Table5: Cronbach's alpha Reliability Statistics.[32]

\begin{tabular}{|c|c|}
\hline $\begin{array}{c}\text { Alpha } \\
\text { Cronbach }\end{array}$ & $\begin{array}{l}\text { Numberof } \\
\text { elements }\end{array}$ \\
\hline 0.878 & 11 \\
\hline
\end{tabular}

The value of the coefficient we have obtained is 0.878 , which is interpreted as good reliability.

\section{Conclusions}

As a result of the analysis of the problem of the lack of motivation to use virtual learning tools at UNMSM, it is concluded that only $30 \%$ of students who take several courses virtually within their curriculum feel comfortable with this type of methodology because it requires an entirely didactic and easy to handle system to carry the teaching material; To improve this percentage we evaluated the type of E-learning platform to be used to take advantage of the changes that are currently taking place to explore all the necessary resources to invest in a good quality virtual tool and after the analysis of the data obtained in the surveys conducted, we obtained that the factors that influence virtual teaching are as follows:

- $\quad$ ICTs are necessary for the daily life of the student today due to the pandemic.

- E-learning platforms are practical and dynamic means to obtain new knowledge.

- Technological attitude, students are able and willing to acquire new knowledge through new learning methodologies using virtual media.

- Continuous training, teachers, students, and administrative staff must be constantly trained and updated to use E-learning tools correctly.

- Ubiquitous adaptability, the virtual platforms must be adapted for laptops, PCs, mobile devices, or tablets; and these must be portable.

The methodology to be used for the proper use of E-learning platforms, according to this research, is the Flipped Classroom or B-learning (Blended or Semi face-to-face). The latter will be necessary when face-to-face classes are retaken in the future. The teacher may decide to apply it synchronously or asynchronously as appropriate.

We are entering a new world where technology is imposing itself on our life habits, mainly because it is already necessary. We must be open to change and allow new creations, and be part of them..

\section{References}

Arbey Edison (2015). Relación entre el uso de técnicas de estudio y la deserción de estudiantes en asignaturas Elearning.

Clark, R. y Mayer R. (2016). E-learning and the Science of Instruction. Proven Guidelines for Consumers and Designers of Multimedia Learning, 4th Edition. ISBN 9781119158660.

Ghirardini, B. (2014). Metodologías de E-learning. Roma: FAO (ISBN 978-92-5-307097-8).

Bartolomé Pina, Antonio (2004). Blended Learning. Conceptos Básicos. ISSN: 1133-8482.

Shankarwader Shweta (2019). E-learning versus classroom training. International Research Journal of Engineering and Technology. Vol. 06. Issue 12. ISSN: 2395-0072.

Aznar, Inmaculada ; Cáceres, María y Romero, José (2019). Competencia digital de un tutor E-learning: Un modelo emergente de buenas prácticas docentes en TIC. ISSN 1983-3652.

Yilmaz, Ramazan (2017). Exploring the role of e-learning readiness on student satisfaction and motivation in a flipped classroom. ISSN 0747-5632.

Motta, V., Guillen, R., Rodriguez, C., (2019). Artificial Neural Networks to optimize learning and teaching in engineering careers. Proceedings of the 2019 International Symposium on Engineering Accreditation and Education, ICACIT 2019, 2019, 9130296. EID: 2-s2.0-85084220713

Oliván-Blázquez, Bárbara, Masluk, Ricardo Fueyo Díaz, Santiago Gascón (2019). The use of flipped classroom as an active learning approach improves academic performance in social work: A randomized trial in a university. ISSN 1932-6203. 
Baelo Álvarez, Roberto (2009). Las tecnologías de la información y la comunicación en la educación superior. Estudio descriptivo y de revisión. ISSN: 1681-5653.

Cabero Almenara, Julio (2000). Las nuevas tecnologías de la información y la comunicación: aportaciones a la enseñanza, en Cabero, J. (Ed.): Nuevas Tecnologías aplicadas a la educación. Madrid: Síntesis, Pp. 15-38.

Ortega Carrillo, José Antonio (1997). Nuevas tecnologías y organización escolar: propuesta eco-comunitaria de estructura y uso de los medios didácticos y las tecnologías. Granada: Grupo Editorial Universitario. ISBN 84921660-1-0. Pp. 203-222.

Majó, Joan y Marqués, Pere. (2002). La revolución educativa en la era internet. Colección "Compromiso con la educación”. Barcelona: Cisspraxis.

Haag, Stephen, Cummings, Maeve y McCubbrey Donald J. (2004). Management information systems for the information age ( $4^{\mathrm{a}}$ ed.). New York: McGraw-Hill.

Petrlik, I., Rodriguez, C., Gonzales, P.,(2019) M-Learning applied to the improvement of the learning of university engineering students. Proceedings of the 2019 International Symposium on Engineering Accreditation and Education, ICACIT 2019, 2019, 9130215. doi: 10.1109/ICACIT46824.2019.9130215

Córdova, J., Vega, H., Rodriguez, C., y Escobedo, F. (2020). Digital signature based on asymmetric cryptography for generation of medical history. 3C Tecnología. Glosas de innovación aplicadas a la pyme, 9(4), 65-85. https://doi.org/10.17993/3ctecno/2020.v9n4e36.65-85

Martínez, G., Vega, H., Rodriguez, C., y Guzmán, Y. (2020). Proximity marketing through mobile application with beacon devices. 3C TIC. Cuadernos de desarrollo aplicados a las TIC, 9(4), 89-111. https://doi.org/10.17993/3ctic.2020.94.89-111

Salas, C., Vega, H. y Rodriguez, C. (2021). Contributions to the Technological Adoption Model for the Peruvian Agro-Export Sector. International Journal of E-Adoption (IJEA). DOI: 10.4018/ IJEA.2021010101

Hilario, M., Esenarro, D., Vega, H., Rodríguez C. (2021). Integration of the enterprise information to facilitate decision making. Journal of contemporary issues in business and government. Vol. 27, No. 1. E-ISSN: 13236903.

Gayle, Dennis, Tewarie, Bhoendradatt y White, A. Quinton Jr. (2003). "Challenges to University Governance Structures" en ASHE-ERIC Higher Education Report núm. 30 vol.1, Washington, DC: Association for the Study of Higher Education, 21-40.

Atencio, Y., Marin, J., Enriquez, R., Rodriguez, C., Petrlik, I.,(2020). A collaborative ide for graphics programming. Journal of Critical Reviews, 2020, 7(15), pp. 1570-1577. doi: 10.31838/jcr.07.15.209

Yrigoyen, Manuel y Torres Paredes, Carlos (2011). Servicios educativos mediante la utilización de tecnologías de Cloud Computing. ISSN: 1993-491

Gutierrez Priego, Ruben y García Peralta, Azahara (2016). ¿Cómo mejorar la calidad, la motivación y el compromiso estudiantil en la educación virtual?. ISSN 2255-1514.

Torres, Ángel Pérez, M. Amor y Romero Luis (2017). Modelo Teórico Integrado de Gamificación en Ambientes E-learning (EMIGA). (DOI: 10.5209)

Poloko N. Ntshwarang, Tumani Malinga y Nonofo Losike-Sedimo (2021). E-learning Tools at the University of Botswana: Relevance and Use under COVID-19 Crisis. DOI: 10.1177/2347631120986281.

Trakru Monica y Tapan Kumar Jha (2019). E-learning Effectiveness in Higher Education. ISSN: 2395-0072

Radha, R. K. Mahalakshmi, Vathish Kumar y Saravana Kumar (2020). E-learning during Lockdown of Covid19 Pandemic: A Global Perspective. ISSN: 2005-4297.

Askar Garad, Abdullah M. Al-Ansi e Ika Nurul Qamari (2021). The role of E-learning infrastructure and cognitive competence in distance learning effectiveness during the COVID-19 Pandemic. DOI: 10.21831

Huanca, Jesús Supo, Felipe Sucari Reynaldo y Supo Luis (2020). El problema social de la educación virtual universitaria en tiempos de pandemia, Perú. ISSN 2215-4132.

George, D., \& Mallery, P. (2003). SPSS for Windows step by step: A simple guide and reference. 11.0 update (4thed.). Boston: Allyn \& Bacon. (ISBN-13: 978-0205011247)

Frías-navarro, D. (2020). Apuntes de consistencia interna de las puntuaciones de un instrumento de medida. Universidad de Valencia. España.

Manrique, Y., y Uc, C.(2020). Desempeño del diseño multimedia en el aprendizaje integral en Educación

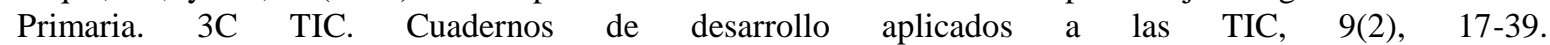
https://doi.org/10.17993/3ctic.2020.92.17-39 